\title{
Atlanta ariejansseni, a new species of shelled heteropod from the Southern Subtropical Convergence Zone (Gastropoda, Pterotracheoidea)
}

\author{
Deborah Wall-Palmer ${ }^{1,2}$, Alice K. Burridge ${ }^{2,3}$, Katja T.C.A. Peijnenburg ${ }^{2,3}$ \\ I School of Geography, Earth and Environmental Sciences, Plymouth University, Drake Circus, Plymouth, PL4 \\ 8AA, UK 2 Naturalis Biodiversity Center, Darwinweg 2, 2333 CR Leiden, The Netherlands 3 Institute for \\ Biodiversity and Ecosystem Dynamics (IBED), University of Amsterdam, P. O. Box 94248, 1090 GE Amster- \\ dam, The Netherlands \\ Corresponding author: Deborah Wall-Palmer (deborah.wall-palmer@plymouth.ac.uk) \\ Academic editor: N. Yonow | Received 21 April 2016 | Accepted 22 June 2016 | Published 11 July 2016 \\ http://zoobank.org/09E534C5-589D-409E-836B-CF64A069939D \\ Citation: Wall-Palmer D, Burridge AK, Peijnenburg KTCA (2016) Atlanta ariejansseni, a new species of shelled \\ heteropod from the Southern Subtropical Convergence Zone (Gastropoda, Pterotracheoidea). ZooKeys 604: 13-30. \\ doi: $10.3897 /$ zookeys.604.8976
}

\begin{abstract}
The Atlantidae (shelled heteropods) is a family of microscopic aragonite shelled holoplanktonic gastropods with a wide biogeographical distribution in tropical, sub-tropical and temperate waters. The aragonite shell and surface ocean habitat of the atlantids makes them particularly susceptible to ocean acidification and ocean warming, and atlantids are likely to be useful indicators of these changes. However, we still lack fundamental information on their taxonomy and biogeography, which is essential for monitoring the effects of a changing ocean. Integrated morphological and molecular approaches to taxonomy have been employed to improve the assessment of species boundaries, which give a more accurate picture of species distributions. Here a new species of atlantid heteropod is described based on shell morphology, DNA barcoding of the Cytochrome Oxidase I gene, and biogeography. All specimens of Atlanta ariejansseni sp. $\mathbf{n}$. were collected from the Southern Subtropical Convergence Zone of the Atlantic and Indo-Pacific oceans suggesting that this species has a very narrow latitudinal distribution $\left(37-48^{\circ} \mathrm{S}\right)$. Atlanta ariejansseni $\mathbf{s p .} \mathbf{n}$. was found to be relatively abundant (up to 2.3 specimens per $1000 \mathrm{~m}^{3}$ water) within this narrow latitudinal range, implying that this species has adapted to the specific conditions of the Southern Subtropical Convergence Zone and has a high tolerance to the varying ocean parameters in this region.
\end{abstract}

\section{Keywords}

Atlantidae, biogeography, DNA barcoding, shelled heteropod, southern subtropical convergence zone

Copyright Deborah Wall-Palmer et al. This is an open access article distributed under the terms of the Creative Commons Attribution License (CC BY 4.0), which permits unrestricted use, distribution, and reproduction in any medium, provided the original author and source are credited. 


\section{Introduction}

The Southern Ocean Sub-Tropical Front (STF) is the boundary between the colder, fresher Sub-Antarctic Zone (SAZ) and the warmer, more saline subtropical waters to the north (Orsi et al. 1995). The Southern Subtropical Convergence Zone (SSTC) is a narrow region along the STF with highly variable physical parameters experiencing strong currents and large gradients of salinity and temperature (Longhurst 1998, Graham and Boer 2013). The STF acts as a dispersal barrier for many zooplankton taxa, resulting in changes in genetic population structure and biomass across this front (Labat et al. 2001, Hiral et al. 2015, Burridge et al. in review a, b). This region is also at a high risk from ocean changes, particularly ocean acidification, because of the high solubility of $\mathrm{CO}_{2}$ in cold water (Roberts et al. 2014).

The shelled atlantid heteropods are likely to be particularly susceptible to ocean acidification. Although, to date, there have been no studies into the effects of ocean changes upon atlantids, we can expect that they will react in a similar way to the shelled pteropods (Thecosomata). While not closely related, atlantids share many of the characteristic features that make shelled pteropods vulnerable to ocean acidification. These include living in the upper layers of the ocean, one of the areas most affected, and producing a very small (up to $\sim 10 \mathrm{~mm}$ ), thin shell of aragonite, which is particularly vulnerable to dissolution in waters undersaturated with carbonate (Fabry et al. 2008). In pteropods, synergistic effects of decreasing carbonate saturation and increasing temperature has been shown to reduce the ability to produce aragonite shells (e.g. Lischka and Riebesell 2012). These effects have already been recorded in natural populations living at high latitudes (Bednaršek et al. 2012), which are predicted to be affected first (Steinacher et al. 2009). However, improvements in taxonomy are extremely important to understanding the effects of these changes on holoplanktonic gastropods. Roberts et al. (2014) found that different forms of the pteropod species Limacina helicina (Phipps, 1774), living in the same area of the Southern Ocean, showed opposing trends in shell weight over a long-term study. This demonstrates the importance of assessing species boundaries in order to fully understand the effects of a changing ocean.

Here an integrated morphological and molecular approach is used to present a new species of atlantid heteropod, Atlanta ariejansseni, that is restricted to a narrow transitional zone of only $11^{\circ}$ of latitude within the SSTC, but has a circumpolar longitudinal range. In common with other sub-polar planktonic gastropod species, $A$. ariejansseni reaches relatively high abundances compared to other atlantids and is the dominant atlantid species living in this area. Most atlantid species are thought to be restricted to warmer tropical and sub-tropical waters, with only one other species, Atlanta californiensis Seapy \& Richter, 1993, showing a preference for cold water regions in the California Current. Atlanta ariejansseni is the only atlantid species specific to sub-polar waters and that appears to be tolerant of such a variable environment. 


\section{Methods}

All specimens examined and included in this study were recorded within the SSTC, between $37^{\circ} \mathrm{S}$ and $48^{\circ} \mathrm{S}$ (Fig. 1). A total of 184 specimens of $A$. ariejansseni were examined from a number of sources (Table 1). From the Atlantic Ocean, 164 specimens for combined molecular and morphological analysis were collected during the Atlantic Meridional Transects AMT20 and AMT24 (Burridge et al. in review a). On both cruises, specimens were caught using a WP2 bongo net with an aperture diameter of $0.71 \mathrm{~m}$ and a mesh of $200 \mu \mathrm{m}$. Specimens from AMT24 were fixed and preserved in $96 \%$ ethanol and stored at $-20{ }^{\circ} \mathrm{C}$ prior to DNA barcoding. Specimens from AMT20 were fixed and stored in $96 \%$ ethanol and stored at room temperature. Storage at room temperature is not optimal for the preservation of DNA; therefore, specimens from AMT20 were not used for DNA barcoding. From the Pacific Ocean, two further specimens, collected by Erica Goetze during the DRFT cruise of the RV Revelle in 2001, were used for molecular analysis (Table 1). Finally, 18 Indo-Pacific specimens were examined from sediment trap samples, collected from south of Tasmania between 1997-2006 by the Antarctic Climate and Ecosystems Cooperative Research Centre (Bray et al. 2000, Roberts et al. 2011). Upon removal from the sediment traps, specimens were washed in buffered peroxide to remove organic matter and dried.

Two published records of atlantids are also available for this region and both are considered here to include misidentified specimens of $A$. ariejansseni sp. n. Howard et al. (2011) recorded 14 specimens of Atlanta gaudichaudi Gray, 1850 in net hauls and a sediment trap positioned south of Tasmania. However, specimens from the same sediment traps (Roberts et al. 2011) that were re-examined for this study were also originally misidentified as $A$. gaudichaudi. A single image of a specimen caught by Howard et al. (2011) is morphologically consistent with $A$. ariejansseni, but is too small to identify with certainty.

Pilkington (1970) described a single species of atlantid, provisionally identified as Atlanta helicinoidea Gray, 1850, off-shore of Taiaroa Head, New Zealand. Pilkington (1970) found it difficult to identify specimens to species level, noting that the morphology did not agree perfectly with any of the atlantid species that had already been described. The detailed descriptions and figures presented by Pilkington (1970) unquestionably resemble the shell morphology of $A$. ariejansseni. Moreover, descriptions of the juvenile stages made by Pilkington (1970) match the juvenile specimens that were examined for this study. Therefore, the Atlanta specimens described by Pilkington (1970) are considered to be $A$. ariejansseni.

\section{DNA barcoding}

A total of 17 undamaged adult $(\mathrm{N}=9)$ and juvenile $(\mathrm{N}=8)$ specimens of $A$. ariejansseni were selected from samples collected during AMT24 and DRFT research 


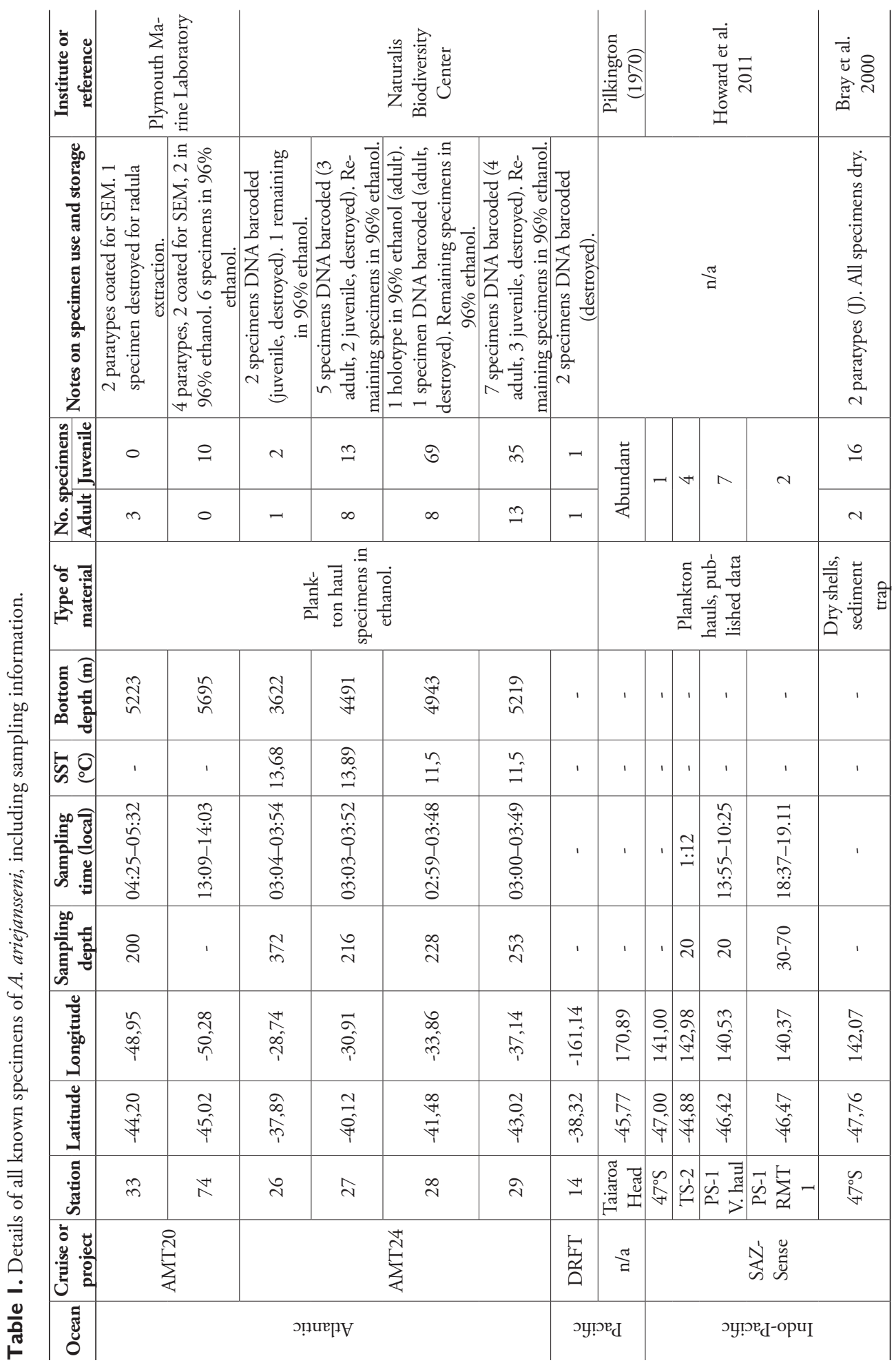




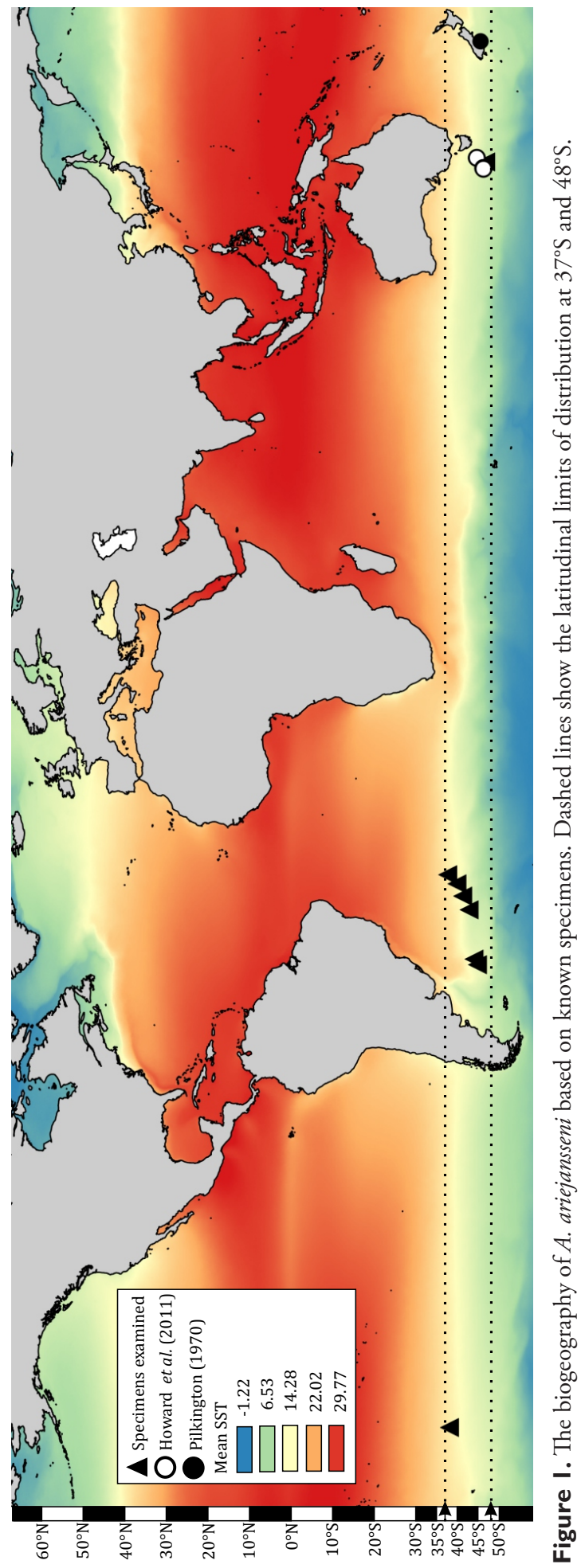


Table 2. Original specimen codes and GenBank accession numbers for all specimens included in the phylogenetic analysis (Fig. 2).

\begin{tabular}{|c|c|c|}
\hline Species & Specimen code or reference & GenBank accession number \\
\hline \multirow{17}{*}{ Atlanta ariejansseni } & Aari_AMT24_26_01 & KX343177 \\
\hline & Aari_AMT24_26_02 & KX343178 \\
\hline & Aari_AMT24_27_01 & KX343179 \\
\hline & Aari_AMT24_27_02 & KX343180 \\
\hline & Aari_AMT24_27_03 & KX343181 \\
\hline & Aari_AMT24_27_04 & KX343182 \\
\hline & Aari_AMT24_27_05 & KX343183 \\
\hline & Aari_AMT24_28_01 & KX343184 \\
\hline & Aari_AMT24_29_01 & KX343185 \\
\hline & Aari_AMT24_29_02 & KX343186 \\
\hline & Aari_AMT24_29_03 & KX343187 \\
\hline & Aari_AMT24_29_04 & KX343188 \\
\hline & Aari_AMT24_29_05 & KX343189 \\
\hline & Aari_AMT24_29_06 & KX343190 \\
\hline & Aari_AMT24_29_07 & KX343191 \\
\hline & Aari_DRFT_14_01 & KX343192 \\
\hline & Aari_DRFT_14_02 & KX343193 \\
\hline \multirow{5}{*}{ Atlanta selvagensis } & Asel_AMT24_05_03 & KX343194 \\
\hline & Asel_AMT24_06_01 & KX343195 \\
\hline & Asel_AMT24_06_02 & KX343196 \\
\hline & Asel_AMT24_06_04 & KX343197 \\
\hline & Asel_AMT24_14_02 & KX343198 \\
\hline \multirow{2}{*}{ Atlanta gaudichaudi } & \multirow{4}{*}{ Jennings et al. 2010} & FJ876837 \\
\hline & & FJ876839 \\
\hline \multirow{2}{*}{ Oxygyrus inflatus } & & FJ876848.1 \\
\hline & & FJ876849.1 \\
\hline \multirow{8}{*}{ Protatlanta souleyeti } & \multirow{8}{*}{ Wall-Palmer et al. in press } & KU841501 \\
\hline & & KU841495 \\
\hline & & KU841506 \\
\hline & & KU841502 \\
\hline & & KU841497 \\
\hline & & KU841494 \\
\hline & & KU841496 \\
\hline & & KU841493 \\
\hline \multirow{2}{*}{ Pterotrachea coronata } & \multirow{6}{*}{ Jennings et al. 2010} & FJ876852.1 \\
\hline & & FJ876853.1 \\
\hline \multirow{2}{*}{ Pterotrachea hippocampus } & & FJ876854.1 \\
\hline & & FJ876855.1 \\
\hline \multirow{2}{*}{ Firoloida desmarestia } & & FJ876850.1 \\
\hline & & FJ876851.1 \\
\hline
\end{tabular}




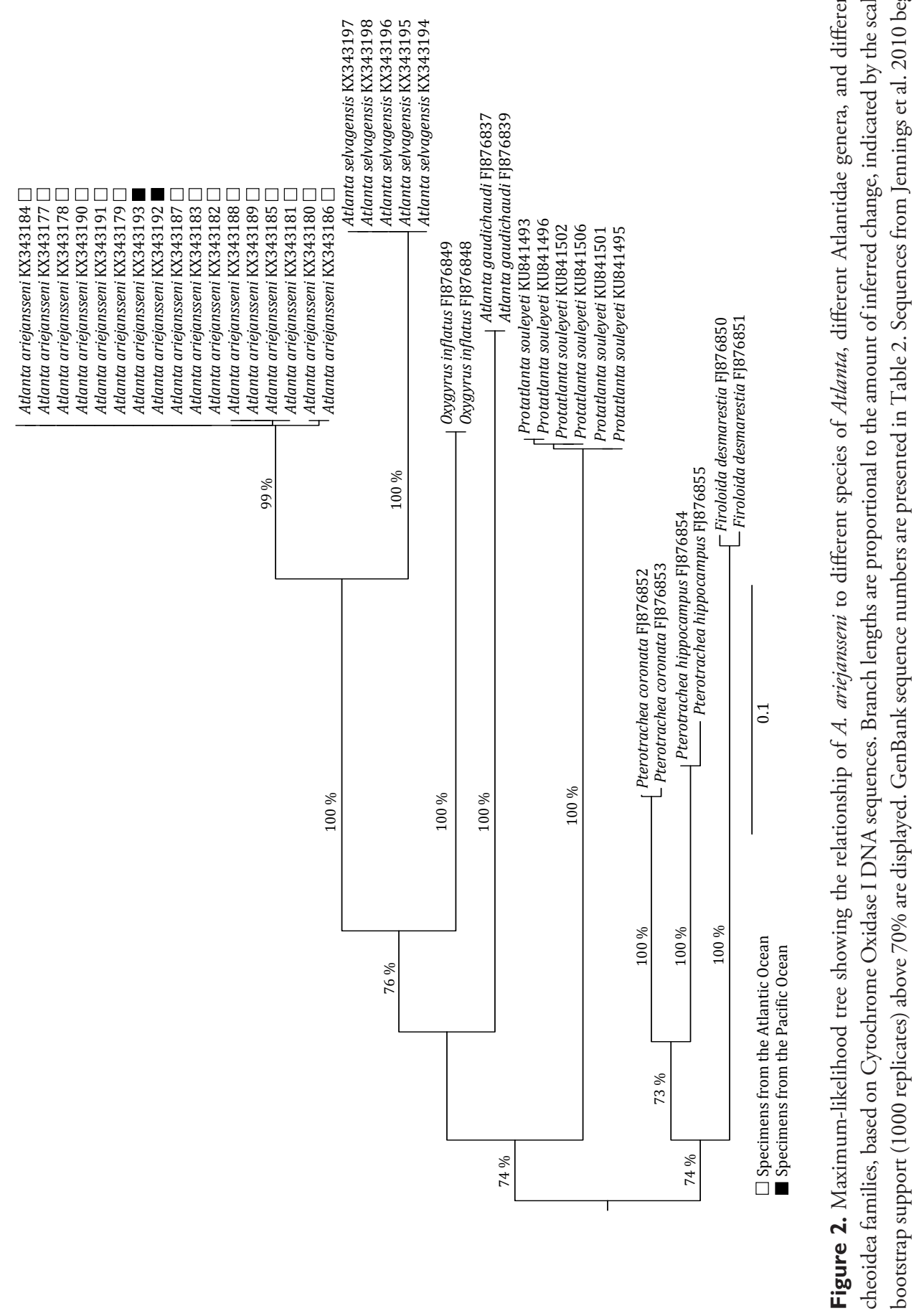


Table 3. Average K2P distances between $A$. ariejansseni and the Atlantidae species $A$. gaudichaudi, A. selvagensis, Protatlanta souleyeti and Oxygyrus inflatus.

\begin{tabular}{l|c|c|c|c}
\hline & A. ariejansseni & A. gaudichaudi & A. selvagensis & P. souleyeti \\
\hline A. ariejansseni $(\mathrm{n}=17)$ & & & & \\
\hline A. gaudichaudi $(\mathrm{n}=2)$ & 0,25 & & & \\
\hline A. selvagensis $(\mathrm{n}=5)$ & 0,14 & 0,27 & & \\
\hline P. souleyeti $(\mathrm{n}=6)$ & 0,26 & 0,24 & 0,24 & \\
\hline O. inflatus $(\mathrm{n}=2)$ & 0,22 & 0,25 & 0,25 & 0,25 \\
\hline
\end{tabular}

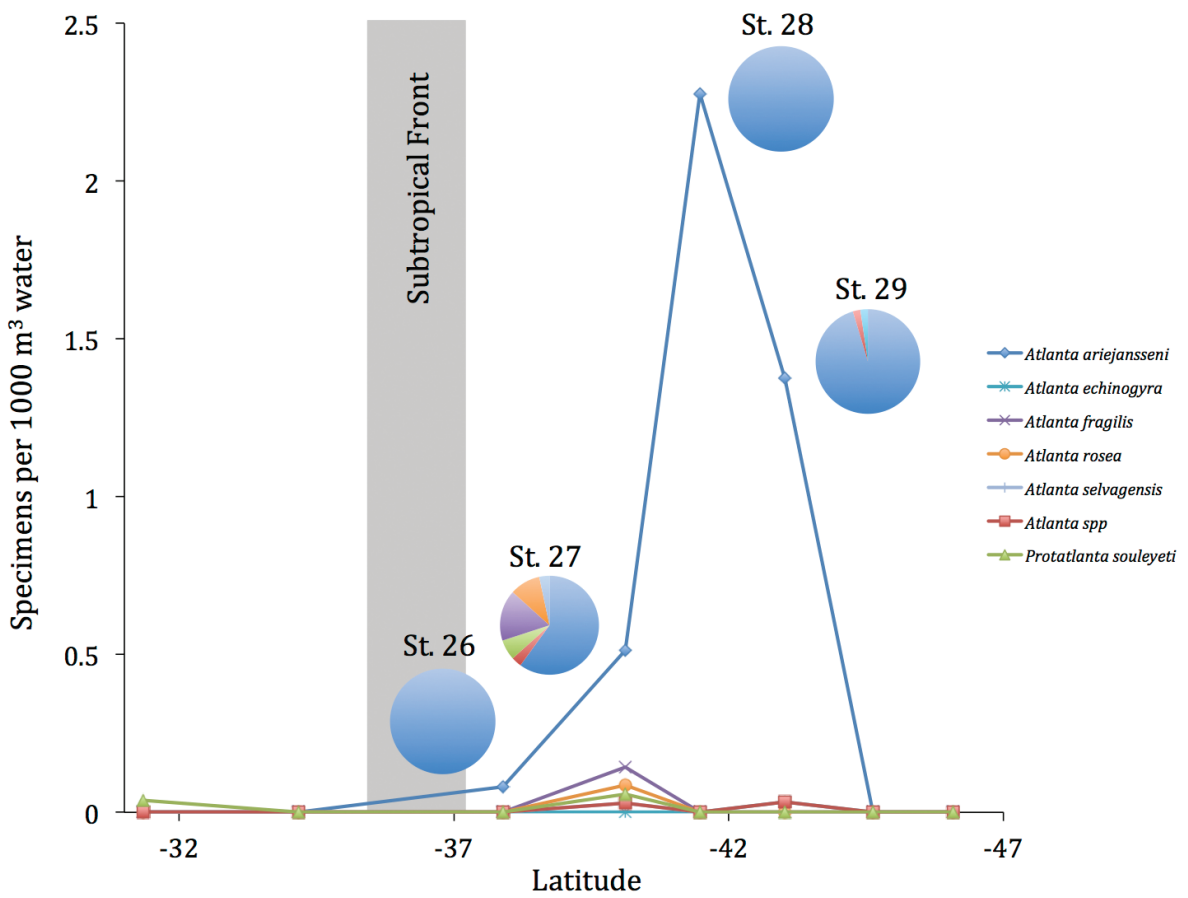

Figure 3. Abundance and pie charts of relative abundance (\%) of atlantids at southern Atlantic stations of the AMT24 cruise.

cruises. DNA barcoding was also carried out for the morphologically similar species Atlanta selvagensis de Vera \& Seapy, 2006 from the Atlantic Ocean. Five specimens of adult $(\mathrm{N}=2)$ and juvenile $(\mathrm{N}=3)$ A. selvagensis were selected from AMT24 sites (St. $5,34.75^{\circ} \mathrm{N}, 26.62^{\circ} \mathrm{W}$; St. $6,31.30^{\circ} \mathrm{N}, 27.73^{\circ} \mathrm{W}$ and St. $14,3.8^{\circ} \mathrm{N}, 25.78^{\circ} \mathrm{W}$ ). All specimens were imaged prior to analysis using a Zeiss automated z-stage light microscope. DNA was extracted from whole specimens, using the NucleoMag 96 Tissue kit by Macherey-Nagel on a Thermo Scientific KingFisher Flex magnetic bead extraction robot, with a final elution volume of $75 \mu \mathrm{l}$. A standard Cytochrome Oxidase I (COI) barcoding fragment (Hebert et al. 2003) was amplified using primers jgLCO1490 and jgHCO2198 (Geller et al. 2013). Primers were tailed with M13F 
and M13R for sequencing (Messing 1983). PCR reactions contained $17.75 \mu \mathrm{mQ}$, $2.5 \mu \mathrm{l}$ 10x PCR buffer CL, $0.5 \mu \mathrm{l} 25 \mathrm{mM} \mathrm{MgCl}_{2}, 0.5 \mu \mathrm{l} 100 \mathrm{mM} \mathrm{BSA}, 1.0 \mu \mathrm{l} 10 \mathrm{mM}$ of each primer, $0.5 \mu \mathrm{l} 2.5 \mathrm{mM}$ dNTPs and $0.25 \mu \mathrm{l}$ 5U Qiagen Taq, with $1.0 \mu \mathrm{l}$ of template DNA, which was diluted 10 or 100 times for some samples. PCR was performed using an initial denaturation step of $180 \mathrm{~s}$ at $94^{\circ} \mathrm{C}$, followed by 40 cycles of $15 \mathrm{~s}$ at $94^{\circ} \mathrm{C}, 30 \mathrm{~s}$ at $50^{\circ} \mathrm{C}$ and $40 \mathrm{~s}$ at $72{ }^{\circ} \mathrm{C}$, and finishing with a final extension of $300 s$ at $72^{\circ} \mathrm{C}$ and pause at $12^{\circ} \mathrm{C}$. Sequencing was carried out by Macrogen, Europe.

All sequences were aligned and edited using the ClustalW algorithm in MEGA 6 (Tamura et al. 2013) and submitted to GenBank (Fig. 2, Table 2). Previously published COI sequences from GenBank (Jennings et al. 2010, Wall-Palmer et al. in press), identified as Atlanta inclinata Gray, 1850, Oxygyrus inflatus Benson, 1835, Firoloida desmarestia Lesueur, 1817, Pterotrachea hippocampus Philippi, 1836, Pterotrachea coronata Forsskål in Niebuhr, 1775 and Protatlanta souleyeti (Smith, 1888), were added to represent the families and genera most closely related to $A$. ariejansseni. Based on these data, a maximum-likelihood tree was constructed in MEGA6 using nucleotide sequences in a General Time Reversible model with gamma distribution and invariant sites $(\mathrm{GTR}+\mathrm{G}+\mathrm{I})$ and 1000 bootstraps. Kimura-2-parameter (K2P) genetic distances were calculated between and within species belonging to the family Atlantidae using MEGA 6 (Tamura et al. 2013).

\section{Results and discussion}

\section{Genetic diversity}

DNA barcoding of seventeen $A$. ariejansseni specimens and five $A$. selvagensis specimens from the southern Atlantic $(\mathrm{N}=15, \mathrm{~N}=5$ respectively) and Pacific $(\mathrm{N}=2, \mathrm{~N}$ $=0$ respectively) oceans shows that $A$. ariejansseni forms a monophyletic group with a bootstrap support of $100 \%$ (Fig. 2). Atlanta ariejansseni has an average K2P distance of 0.14-0.25 from other species in the genus Atlanta and 0.22-0.26 from other genera of Atlantidae (Oxygyrus and Protatlanta respectively, Table 3).

\section{Biogeography}

All known specimens of $A$. ariejansseni were collected between $37^{\circ} \mathrm{S}$ and $48^{\circ} \mathrm{S}$ (Table 1) within the SSTC in water temperatures of $6.5-14.3^{\circ} \mathrm{C}$ (Fig. 1). Along the AMT24 transect, the most northern occurrence of the key thecosome pteropod species Limacina helicina antarctica Woodward, 1854 was at St. $26\left(31.34^{\circ} \mathrm{S}\right)$, the same station as $A$. ariejansseni (Burridge et al. in review a). However, the range of $L$. helicina antarctica extends much further south than $A$. ariejansseni, which, along with all other atlantid species, were not found at sites south of $48^{\circ} \mathrm{S}$. In the Atlantic Ocean, $A$. ariejansseni was found at four AMT24 stations (St. 26-29) between $37^{\circ} \mathrm{S}$ and $43^{\circ} \mathrm{S}$. Atlanta ariejans- 
seni was found to be the most abundant atlantid at these stations and the only species present at stations 26 and 28 (Fig. 3). At a latitude of $-41.47^{\circ} \mathrm{S}, \mathrm{A}$. ariejansseni reached a maximum abundance of 2.3 specimens per $1000 \mathrm{~m}^{3}$.

Specimens of $A$. ariejanssen $i$ have been caught at different times of the day in the upper $372 \mathrm{~m}$ of the water column (Table 1). Low numbers of specimens were caught at the ocean surface $(20-70 \mathrm{~m})$ at all times of the day. However, highest numbers were caught in 228-253 m water depth at night between 03:00 and 04:00 local time (Table 1).

\section{Systematics}

Phylum MOLLUSCA

Class GASTROPODA Cuvier, 1797

Subclass CAENOGASTROPODA Cox, 1960

Order LITTORINIMORPHA Golikov \& Starobogatov, 1975

Superfamily PTEROTRACHEOIDEA Rafinesque, 1814

Family ATLANTIDAE Rang, 1829

Genus Atlanta Lesueur, 1817

\section{Atlanta ariejansseni sp. n.} http://zoobank.org/7E9AEE5E-5F7F-480C-9673-89A3E9979FE9

Figures 4-6

Type locality. AMT24 station $28,41.48^{\circ} \mathrm{S}, 33.86^{\circ} \mathrm{W}$. Specimen collected on the $27^{\text {th }}$ October 2014 at 02:59-03:48 local time at a water depth of 0-228 m.

Holotype. Figure $5 \mathrm{j}-1$. Housed at the Naturalis Biodiversity Center, Leiden, accession number RMNH.5004155. For specimen dimensions, see Table 4. Collected by Alice K Burridge.

Paratypes. Figure $4 a-i$ and k. See Table 4 for details.

Additional material. See Table 1.

Diagnosis. Atlanta species with a spire of $31 / 4$ to $3 \frac{1}{2}$ whorls. The spire is moderately high, rounded and with deep sutures and covered in small, low projections approximately arranged in lines.

Description. Shell small and transparent, with adult shells ranging from 2012 to $3059 \mu \mathrm{m}$ in diameter excluding the keel and 2237 to $3370 \mu \mathrm{m}$ including the keel in examined material. The shell inflates at $31 / 4$ to $3 \frac{1}{2}$ whorls and has a total of $4 \frac{1}{2}$ to 4 $3 / 4$ whorls. The keel begins at $33 / 4$ whorls and inserts between the final whorl and the spire for around $1 / 4$ whorl. The keel is tall and gradually truncated with a yellow-brown keel base. The keel often has a slightly undulating shape. The soft tissue varies greatly in colour among individuals from mottled white to orange-pink and dark grey (Fig. 5). Some specimens were observed to have a pearlescent lustre to the shell surface.

The spire is moderately high, well-visible in apertural view, with deep sutures, giving the whorls a rounded appearance (Fig. 6). The spire surface is ornamented with numer- 


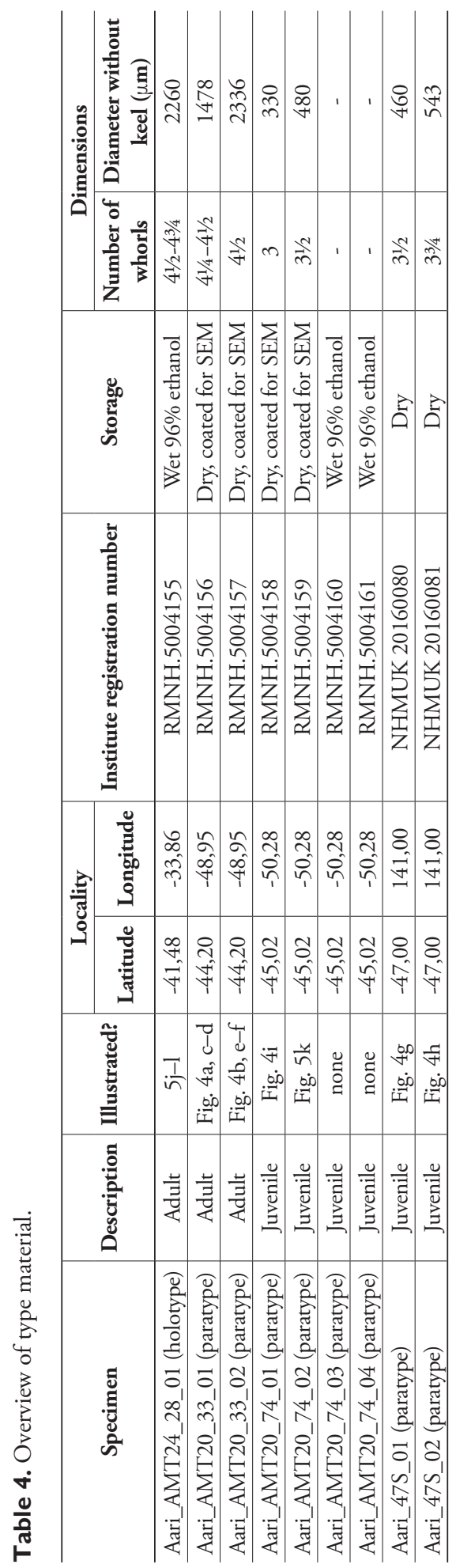



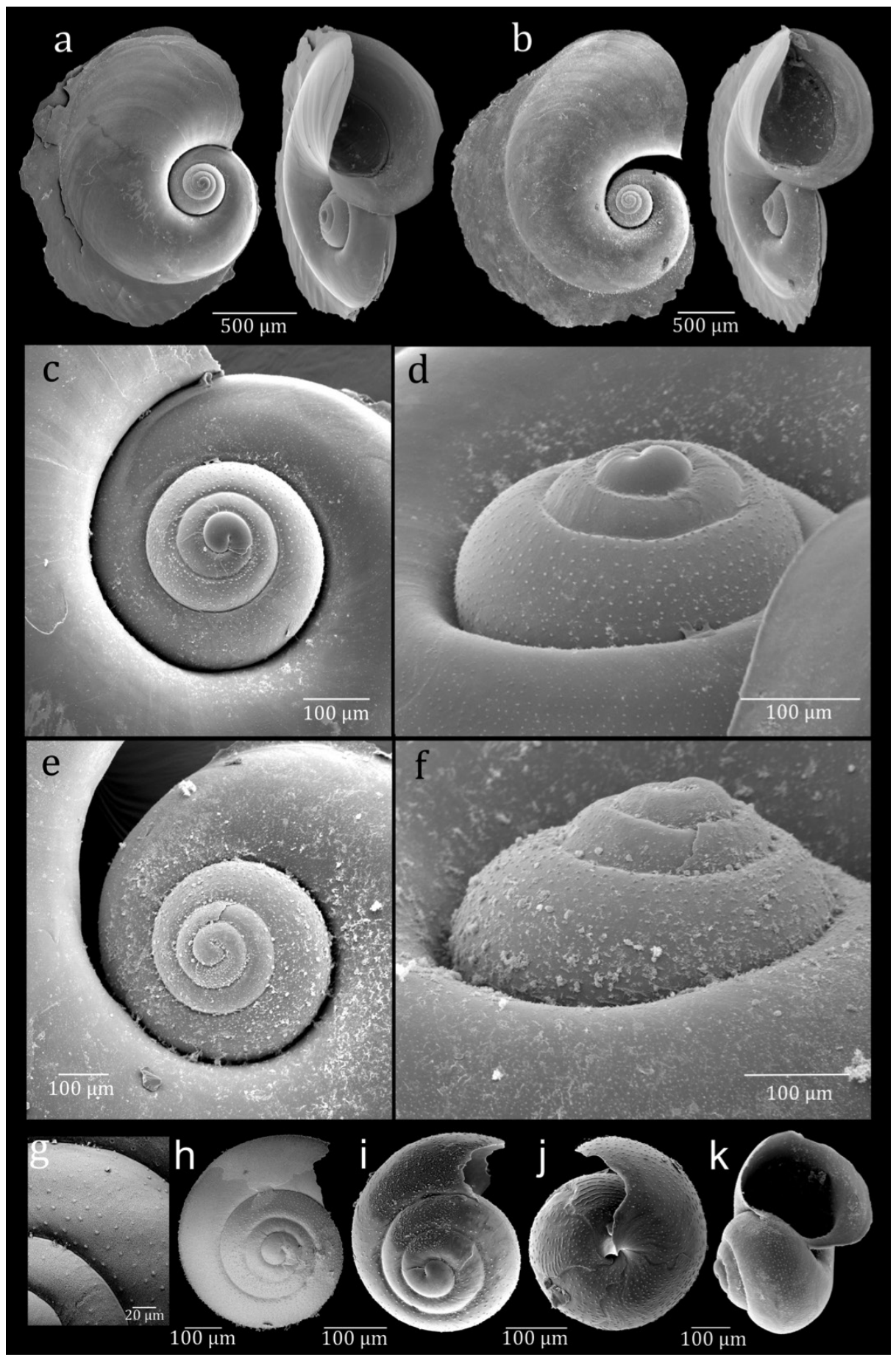

Figure 4. SEM images of $A$. ariejansseni. Aari_AMT20_33_01 (a, c-d); Aari_AMT20_33_02 (b, e-f); Aari_47S_01 (g); Aari_47S_02 (h); Aari_AMT20_74_01 (i); Aari_AMT20_74_05 (j); Aari_ AMT20_74_02 (k). Specimens $g$ and h were imaged using low vacuum SEM and were not sputter coated. 


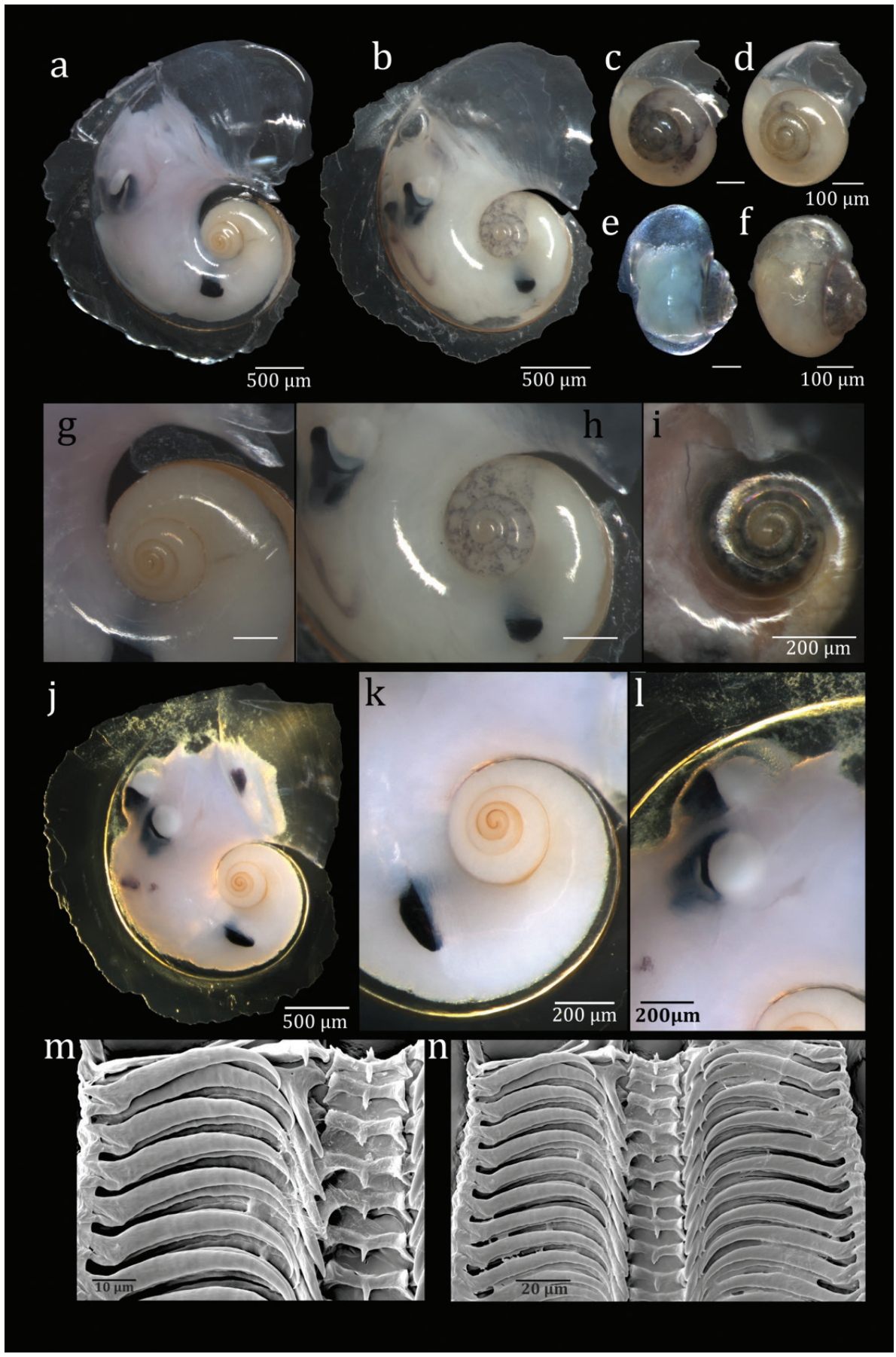

Figure 5. Stacking light microscopy images of $A$. ariejansseni showing variations in tissue colour. Aari_ AMT24_29_01 (a, g); Aari_AMT24_27_01 (b, h); Aari_AMT24_26_01 (c); Aari_AMT24_26_02 (d); Aari_AMT24_27_04 (e); Aari_AMT24_27_04 (f); Aari_AMT24_28_01 (i); Aari_AMT24_28_01 (j-l); Radula of Aari_AMT20_33_03 (m-n). 


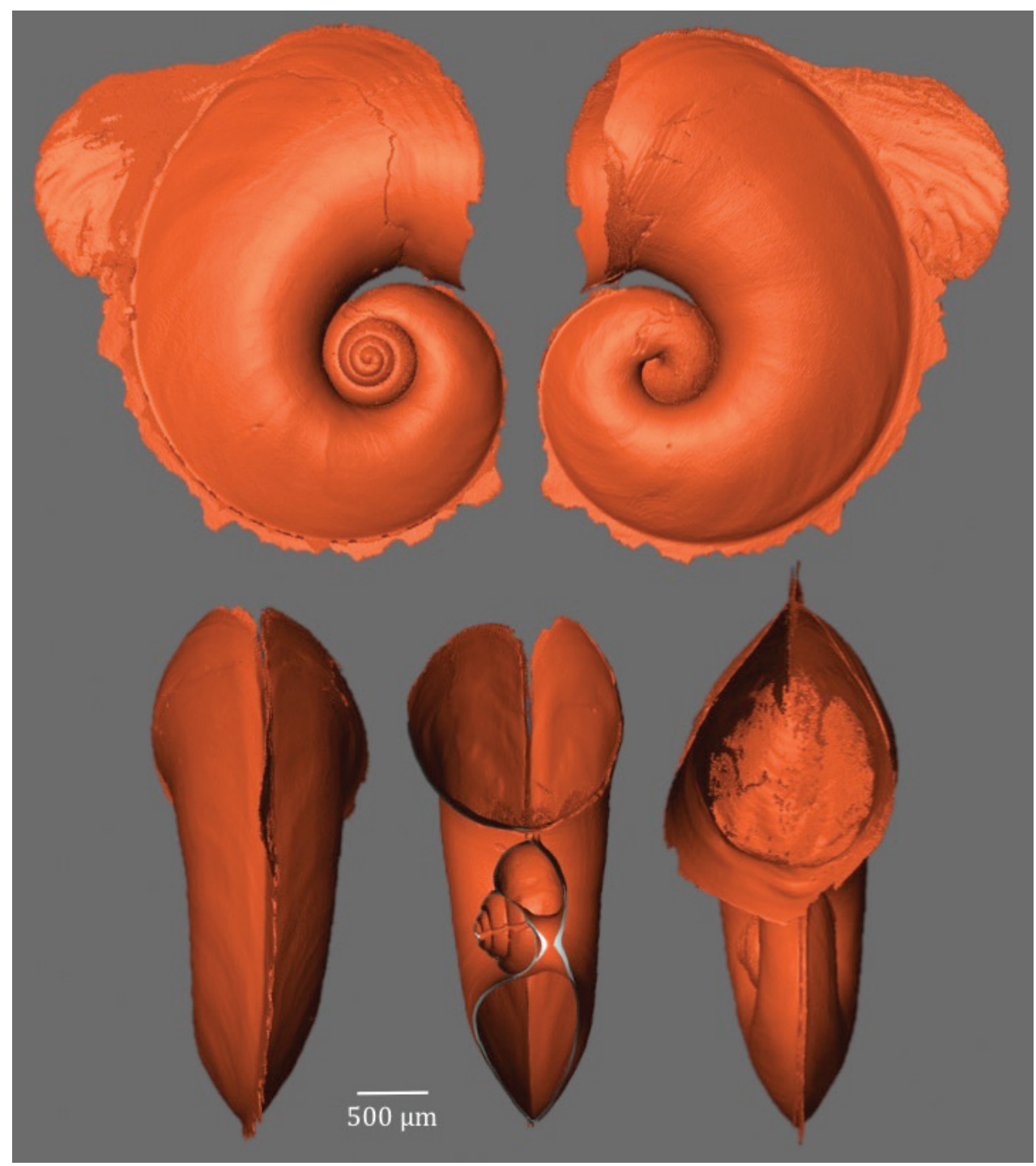

Figure 6. X-ray tomography of $A$. ariejansseni specimen Aari_AMT20_33_03.

ous low projections in the form of punctae roughly arranged in 9-12 spiral rows over the surface of whorls 2-4 (Fig. 4). These low projections can vary in their spatial coverage, from closely spaced to sparse (Fig. $4 \mathrm{~g}-\mathrm{h}$ ). This gives the spire a rough appearance under a light microscope. The projections are clearly visible using SEM (Fig. 4). No other species of atlantid has been found with this type of micro-ornamentation in the inner spire. Juvenile specimens have approximately six fine lines of small projections running around the side of the shell, although these are not always obvious under light microscopy. Around the base of the juvenile shell the projections can become so closely positioned that they become irregular, frequently interrupted spiral lines in some specimens (Fig. 4j) 
The operculum is type c, the radula is type I (Fig. $5 \mathrm{~m}-\mathrm{n}$ ) and the eyes are of type a (Seapy et al. 2003), with no transverse slit (Fig. 5h and l).

Discussion. The rounded spire, number whorls, opercular, radula and eye type all suggest that $A$. ariejansseni belongs within the Atlanta inflata group of Richter and Seapy (1999). The most morphologically similar species are Atlanta californiensis and A. selvagensis. Atlanta californiensis has the same number of whorls in the spire and the same overall adult shape as A. ariejansseni, but it does not have any shell ornamentation. Atlanta californiensis also has much shallower spire sutures than $A$. ariejansseni. Atlanta selvagensis is a slightly smaller species that does show shell ornamentation of the spire in the form of spiral lines that are frequently interrupted and highly variable; however, the ornamentation of $A$. ariejansseni can clearly be distinguished from that of $A$. selvagensis. Molecular results presented here also confirm that the two species are closely related, but separated by a K2P genetic distance of 0.14 . No molecular data is available for $A$. californiensis.

Previous publications have identified $A$. ariejansseni as A. gaudichaudi (Howard et al. 2011) and $A$. helicinoidea (Pilkington 1970). However, these two species are also morphologically different from $A$. ariejansseni. Although $A$. helicinoidea belongs to the $A$. inflata group, the spire has an extra whorl and the ornamentation is much coarser than that of $A$. ariejansseni. Atlanta gaudichaudi is described as having no shell ornamentation, although some authors show this species with a single spiral line on the spire (Seapy et al. 2003). However, A. gaudichaudi does not have the low projections that are found on the spire of $A$. ariejansseni. DNA barcoding also shows that these two species are not closely related, with an average K2P genetic distance of 0.25 .

Distribution. All specimens were found between $37^{\circ} \mathrm{S}$ and $48^{\circ} \mathrm{S}$ latitude, in a narrow circumtropical band located in the Southern Subtropical Convergence Zone. Specimens were collected from the epipelagic layer (upper $372 \mathrm{~m}$ ) using oblique plankton tows in the Atlantic and Pacific oceans. For a summary of biogeography and sampling information, see Fig. 1 and Table 1.

Etymology. Named after Arie Janssen, Naturalis Biodiversity Center, Netherlands, in recognition of his commitment and longstanding contributions to holoplanktonic gastropod research.

\section{Conclusions}

Combined molecular, morphological, and biogeographical information has allowed the introduction of a new species of the genus Atlanta that can be easily identified by means of its shell ornamentation using light microscopy. Atlanta ariejansseni is the only atlantid species that has been found living at high latitudes, restricted to a narrow circumpolar region. It is, therefore, an extremely important species in the current race to understand the effects of a changing ocean. It can be assumed that this species is able to tolerate a variable environment, which suggests that it may also be able to adapt to a changing ocean. This resilience and adaptability may be demonstrated by the successful rearing of veliger $A$. ariejansseni through to adults 
under laboratory conditions by Pilkinton (1970), which has never since been accomplished with other atlantid species.

Large sampling efforts have been made for holoplanktonic gastropods in the Southern Ocean; however, $A$. ariejansseni has never been recognised as an undescribed species in these studies. This is undoubtedly due to our incomplete understanding of atlantid taxonomy, particularly for the Atlantic Ocean. We hope that this study will increase awareness of $A$. ariejansseni and encourage others to record this circumpolar species when observed to build up a more complete biogeography. It is only with more biogeographical and ecological data that we will be able to determine the ecology and effects of a changing ocean upon this species.

\section{Acknowledgements}

We are grateful to Donna Roberts (University of Tasmania) for providing specimens from sediment traps from off-shore of Tasmania. The Australian Antarctic Division supports this ongoing sediment trap program (AAS \#1156). We would like to thank Elaine Fileman and Rachel Harmer (Plymouth Marine Laboratory) for providing specimens from AMT20. We are grateful to Aline Nieman, Kevin Beentjes and Frank Stokvis (Naturalis Biodiversity Center) for help with DNA barcoding of specimens and Erica Goetze and Rachel Harmer for plankton collection on cruises AMT20, AMT24 and DRFT. We would like to acknowledge the Plymouth Electron Microscopy Centre and Glenn Harper for help with SEM imaging, the scientists and crew who took part in cruises AMT20, AMT24 and DRFT, and the Atlantic Meridional Transect (AMT) programme. This study is a contribution to the international IMBER project and was supported by the UK Natural Environment Research Council National Capability funding to Plymouth Marine Laboratory and the National Oceanography Centre, Southampton. This is contribution number 302 of the AMT programme. We acknowledge Diamond Light Source for time on Beamline/ Lab I13-2 under Proposal MT12300-1 and Christophe Rau and Andrew Bodey for help with x-ray tomography. We are extremely grateful to María Moreno-Alcántara and Nathalie Yonow for reviewing our manuscript and for their constructive comments. DW-P was funded by the Leverhulme Trust (RPG-2013-363, 2014-2017, PA Christopher Smart, Plymouth University, Co-A Richard Kirby, Marine Biological Association, Plymouth) and a Martin-Fellowship from the Naturalis Biodiversity Center, Leiden (2015).

\section{References}

Bednaršek N, Tarling G, Bakker DCE, Fielding S, Jones EM, Venables HJ, Ward P, Kuzirian A, Lézé B, Feely RA, Murphy EJ (2012) Extensive dissolution of live pteropods in the Southern Ocean. Nature Geoscience 5: 881-885. doi: 10.1038/ngeo1635 
Bray S, Trull T, Manganini S (2000) SAZ project moored sediment traps: Results of the 19971998 deployments. Cooperative Research Centre for Antarctica and the Southern Ocean, Report No. 15. Hobart, Tasmania, 128 pp.

Burridge AK, Goetze E, Wall-Palmer D, Le Double S, Huisman J, Peijnenburg KTCA (in review a) Diversity and abundance of pteropods and heteropods along a latitudinal gradient across the Atlantic Ocean. Progress in Oceanography.

Burridge AK, Tump M, Vonk R, Goetze E, Peijnenburg KTCA (in review b) Diversity and distribution of hyperiid amphipods along a latitudinal transect in the Atlantic Ocean. Progress in Oceanography.

Fabry VJ, Seibel BA, Feely RA, Orr JC (2008) Impacts of ocean acidification on fauna and ecosystem processes. ICES Journal of Marine Science 65: 414-432. doi: 10.1093/icesjms/fsn048

Graham RM, Boer AG (2013) The dynamic Subtropical Front. Journal of Geophysical Research: Oceans 118: 5676-5685. doi: 10.1002/jgrc.20408

Geller J, Meyer C, Parker M, Hawk H (2013) Redesign of PCR primers for mitochondrial cytochrome c oxidase subunit I for marine invertebrates and application in all-taxa biotic surveys. Molecular Ecology Resources 13: 851-861. doi: 10.1111/1755-0998.12138

Hebert PD, Cywinska A, Ball SL (2003) Biological identifications through DNA barcodes. Proceedings of the Royal Society of London. Series B: Biological Sciences 270: 313-321. doi: $10.1098 / \mathrm{rspb} .2002 .2218$

Hiral J, Tsuda A, Goetze E (2015) Extensive genetic diversity and endemism across the global range of the oceanic copepod Pleuromamma abdominalis. Progress in Oceanography 138: 77-90. doi: 10.1016/j.pocean.2015.09.002

Howard WR, Roberts D, Moy AD, Lindsay MCM, Hopcroft RR, Trull TW, Bray SG (2011) Distribution, abundance and seasonal flux of pteropods in the Sub-Antarctic Zone. DeepSea Research II 58: 2293-2300. doi: 10.1016/j.dsr2.2011.05.031

Jennings RM, Bucklin A, Ossenbrügger H, Hopcroft RR (2010) Species diversity of planktonic gastropods (Pteropoda and Heteropoda) from six ocean regions based on DNA barcode analysis. Deep-Sea Research II 57: 2199-2210. doi: 10.1016/j.dsr2.2010.09.022

Labat JP, Mayzaud P, Dallot S, Errhif A, Razouls S, Sabini S (2001) Mesoscale distribution of zooplankton in the Sub-Antarctic Frontal system in the Indian part of the Southern Ocean: a comparison between optical plankton counter and net sampling. Deep-Sea Research I 49: 735-749. doi: 10.1016/S0967-0637(01)00076-0

Longhurst AR (1998) Ecological geography of the sea. Academic Press, San Diego, 398 pp.

Lischka S, Riebesell U (2012) Synergistic effects of ocean acidification and warming on overwintering pteropods in the Arctic. Global Change Biology 18: 3517-3528. doi: 10.1111/ gcb. 12020

Messing J (1983) New M13 vectors for cloning. Methods in Enzymology 101: 20-78. doi: 10.1016/0076-6879(83)01005-8

Orsi A, Whitworth T, Nowlin Jr WD (1995) On the meridional extent and fronts of the Antarctic Circumpolar Current. Deep-Sea Research I 42: 641-673. doi: 10.1016/09670637(95)00021-W

Pilkington MC (1970) Young stages and metamorphosis in an atlantid heteropod occurring off south-eastern New Zealand. Proceedings of the Malacological Society of London 39: 117-124. 
Richter G, Seapy RR (1999) Heteropoda. In: Boltovskoy D (Ed.) South Atlantic zooplankton, 1. Backhuys, Leiden, 621-647.

Roberts D, Howard WR, Roberts JL, Bray SG, Moy AD, Trull TW, Hopcroft RR (2014)

Diverse trends in shell weight of three Southern Ocean pteropod taxa collected with Polar Frontal Zone sediment traps from 1997 to 2007. Polar Biology 37: 1445-1458. doi: 10.1007/s00300-014-1534-6

Roberts D, Howard WR, Moy AD, Roberts JL, Trull T, Bray SG, Hopcroft RR (2011) Interannual pteropod variability in sediment traps deployed above and below the aragonite saturation horizon in the Sub-Antarctic Southern Ocean. Polar Biology 34: 1739-1750. doi: $10.1007 / \mathrm{s} 00300-011-1024-\mathrm{z}$

Seapy RR, Lalli CM, Wells FE (2003) Heteropoda from Western Australian Waters. In: Wells FE, Walker DI, Jones DS (Eds) The marine flora and fauna of Dampier, Western Australia, Western Australia Museum, Perth, 513-546.

Seapy RR, Richter G (1993) Atlanta californiensis, a new species of atlantid heteropod (Mollusca: Gastropoda) from the California Current. The Veliger 36: 389-398.

Steinacher M, Joos F, Frölicher TL, Plattner G-K, Doney SC (2009) Imminent ocean acidification in the Arctic projected with NCAR global coupled carbon cycle-climate model. Biogeosciences 6: 515-533. doi: 10.5194/bg-6-515-2009

Tamura K, Stecher G, Peterson D, Filipski A, Kumar S (2013) MEGA6: molecular evolutionary genetics analysis version 6.0. Molecular Biology and Evolution 30: 2725-19. doi: $10.1093 / \mathrm{molbev} / \mathrm{mst} 197$

Wall-Palmer D, Burridge AK, Peijnenburg KTCA, Janssen A, Kirby R, Hart M, Smart CW (in press) Evidence for the validity of Protatlanta sculpta (Gastropoda: Pterotracheoidea). Contributions to Zoology. 